\title{
IS "ROCKSNOT" (DIDYMOSPHENIA GEMINATA) IN GRAND Teton National Park?
}

\author{
ANGEla M. OSTRANDER, LiSA KunZA AND RoBERT O. HALL JR. \\ UNIVERSITY OF WYOMING LARAMIE
}

\begin{abstract}
$\uparrow \quad$ AbSTRACT
Didymosphenia geminata is a microscopic single-celled freshwater diatom. The invasive behavior of $D$. geminata is greatly altering physical and biological conditions in streams and rivers; the stalk material byproduct that $D$. geminata produces has the potential to cover up to $100 \%$ of stream substrate with a thickness of $20 \mathrm{~cm}$. Even though D. geminata is native to the United States, it is acting like an invasive species. Once only identified in nutrient poor waters, $D$. geminata has been expanding its native range and is occurring more frequently in nutrient-rich streams and rivers. We conducted a survey of $D$. geminata in Grand Teton National Park Wyoming and to our knowledge, this is one of the first surveys examining $D$. geminata in this area. We found and confirmed D. geminata in approximately 7 streams including; Phelps Lake Outlet $1.5 \times 10^{8}$ cells $/ \mathrm{m}^{2}$, Taggert Lake Outlet $2.4 \times 10^{7} \mathrm{cells} / \mathrm{m}^{2}$, Phelps Lake Inlet $2.1 \times 10^{6}$ cells $/ \mathrm{m}^{2}$, Jenny Lake Outlet $8.4 \times 10^{5} \mathrm{cells} / \mathrm{m}^{2}$, Flat Creek $2.9 \times 10^{7}$ cells $/ \mathrm{m}^{2}$, Leigh Lake Outlet $1.3 \times 10^{4}$ cells $/ \mathrm{m}^{2}$, and Fish Creek $9.2 \times 10^{5}$ cells $/ \mathrm{m}^{2}$. Potential commonalities in the sites where $D$. geminata was found and confirmed in Grand Teton National Park include lake outlet streams and high traffic areas.
\end{abstract}

\section{$\downarrow \quad$ INTRODUCTION}

Rock snot, or Didymosphenia geminata, commonly known as 'Didymo', is a microscopic singlecelled freshwater diatom (Figure 1). Diatoms are algal protists that are important primary producers in aquatic systems (Prescott et al. 2005). The cell walls (frustules) of diatoms are made of silica $\left(\mathrm{SiO}_{2}\right)$ and vary greatly in shape and size. D. geminata is one of the largest diatoms at approximately $130 \mu \mathrm{m}$ in length and can be identified by its unique shape. In valve view $D$. geminata has an hour glass/figure-eight conformation, and in its girdle view it is wedge-shaped. One main problem with $D$. geminata is that it is acting as an invasive species and greatly altering physical and biological conditions in streams and rivers.

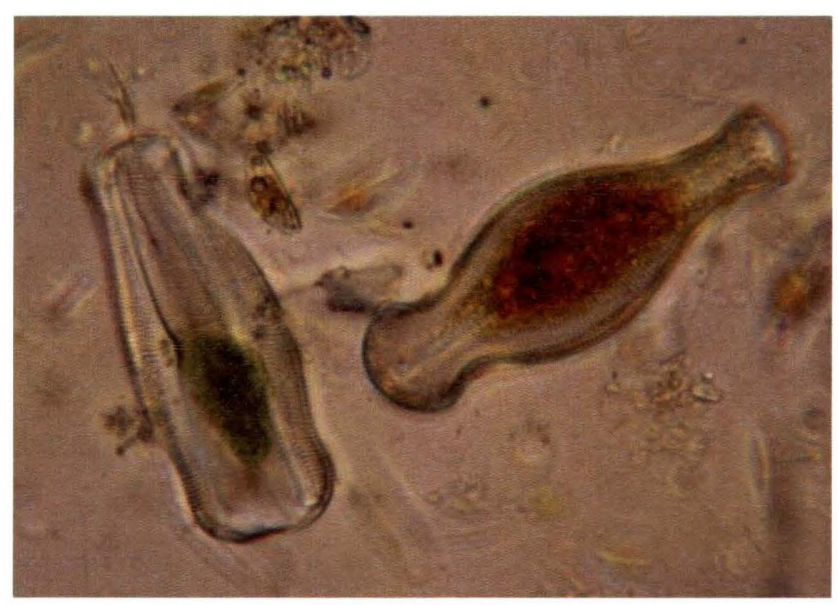

Figure 1. Picture taken by Lisa Kunza: D. geminata shown at $\mathrm{x} 400$ magnification in valve view (right image) and girdle view (left image), sample from Taggert Lake Outlet.

D. geminata itself, however, is not the primary problem, but rather, the stalk material it produces; when the cell dies, this stalk material remains on the stream bottom in a wool-like mat. Mats can cover up to $100 \%$ of stream substrate with a thickness of $20 \mathrm{~cm}$ (Spaulding and Elwell 2007). Such coverage poses a risk of substantial changes in ecological processes such as ecosystem metabolism, nutrient cycling, and animal behaviors, as well as ecological properties such as species diversity, population size, and nutrient pools (Kilroy 2006). For instance, D. geminata mats alter the 
ability of invertebrates with appendages to move, decreasing biodiversity in and around the stream. Therefore, D. geminata mats can impact fish populations.

D. geminata is documented in areas of North America (Canada \& U.S.), Asia (China), Europe (Scotland, Sweden, and Finland), and has been recently documented in New Zealand (Kilroy 2004). Even though D. geminata is present in the United States, information about its native range is limited. In fact, the main diatom identification manual (Patrick and Reimer 1966) only describes $D$. geminata as being present in Virginia. Even though D. geminata is native to North America, it has been acting like an invasive species. D. geminata has been expanding its range. Until recently, $D$. geminata was limited to nutrient-poor waters, but is now occurring more frequently in nutrient-rich streams and rivers (Spaulding and Elwell 2007).

Early detection is key in preventing and/or slowing the spread of $D$. geminata. Early detection increases the potential for successful mitigation of impacts and also enables more efficient targeting of containment, control, and public awareness measures (Schmidt 2007). We are performing a presence/absence survey of $D$. geminata in Grand Teton National Park, Wyoming. To our knowledge this is one of the first surveys examining $D$. geminata in this area.

\section{$\downarrow \quad$ MeTHODS}

\section{Study Area}

Our $D$. geminata research project was divided into two primary portions; field sampling and laboratory work. Field sampling took place in streams located in Grand Teton National Park, Wyoming; some streams located just outside the park were sampled as well to provide a better estimation of $D$. geminata's presence (Figure 2).

We sampled approximately 25 streams including; the streams along the Teton Range, the Snake River and tributaries east of the Snake River such as Pilgrim Creek, Pacific Creek, Arizona Creek, Lizard Creek, Polecat Creek, Spread Creek, and Ditch Creek. A complete list of all streams is in Appendix A. All laboratory work was conducted at the University of Wyoming/National Park Service Research Station and the laboratories located at the University of Wyoming.



Figure 2.Picture adapted from <http://www.colonialvoyage.com $>$. Red dots symbolize areas where $D$. geminata was found and confirmed and blue dots symbolize areas where $D$. geminata was not found: Snake River at South Park Bridge is not shown on the map, however it would be represented with a blue dot as no $D$. geminata was found.

\section{Streamside Procedures}

We searched for $D$. geminata mats at each field location and sampled the mats directly, if present. To do this, we collected five rocks and measurements of $D$. geminata on the rocks were taken. We measured the thickness of $D$. geminata in centimeters and coverage of $D$. geminata on a $10 \mathrm{~cm}^{2}$ area of the rock. We placed mats in Whirl-paks for future reference. We then scrubbed the rocks and the homogenized liquid was placed into two separate $20 \mathrm{~mL}$ scint vials per rock.

We sampled no fewer than 5 cobbles (over 100-200 meters reach) in each stream. Each rock was thoroughly scrubbed into a tray and the homogenized liquid was sub-sampled. We measured the surface area of each rock containing the sample in order to normalize cell counts per unit area; this was done by tracing each rock on Rite-in-the-Rain paper to estimate surface area. 
In order to prevent us from spreading $D$. geminata, we immediately submerged all brushes, graduated cylinders, trays, and shoes worn at the site in $10 \%$ antibacterial detergent solution for more than 30 minutes after being exposed to the stream. It is recommended to use a $5 \%$ solution of bleach or detergent (Spaulding and Elwell 2007); however, we took further precautions by treating our gear with a much higher concentration. We then made a report for each individual stream stating details such as the number of people present at the stream, visual and physical aspects of the stream (GPS coordinates and elevation measurements).

\section{Laboratory Procedures}

We created wet mounts to seek out $D$. geminata at a microscopic level ( 5 slides per rock were observed or 25 slides per stream). Wet mounts were created by placing one drop of homogenized liquid on a microscope slide using a plastic pipette and covering it with a cover glass slip. We looked over the entire area of the cover glass for D. geminata cells and stalk material using a microscope at $100 x$ magnification. If other diatoms or stalk material were present, we made a note of it. If $D$. geminata was present in the slide, each individual cell was counted and documented. To avoid contamination, we used a different microscope slide, cover slip, and plastic pipette for each stream. We then used these values to calculate the concentration of $D$. geminata in the stream (detection limit: $620 \mathrm{cells} / \mathrm{m}^{2}$ ). We stored the second $20 \mathrm{~mL}$ scintillation vial of the remaining sample in $2 \%$ gluteraldehyde to preserve for future reference.

\section{$\uparrow \quad$ Results}

We found and confirmed $D$. geminata in approximately 7 streams, mostly lake outlets. $D$. geminata mats were present in Taggert Lake Outlet where few mats were present and Phelps Lake Outlet where mats were very dense. We found a trend of $D$. geminata presence in lake outlet streams and high traffic areas; areas where people had direct access to the stream or highly traveled areas (bridges, roads, trails, etc.).

\section{DISCUSSION}

We found Didymosphenia geminata inside and outside of Grand Teton National Park, Wyoming. The information gathered from the various streams and rivers where $D$. geminata was not found will provide a valuable reference to prior conditions if this potentially destructive diatom does appear in these areas in the future. Our findings have improved the knowledge about the presence and absence of $D$. geminata in Grand Teton National Park's streams and rivers as well as streams and rivers just outside of the park. Research needs to continue in these areas to better understand not only the presence and absence of D. geminata, but its spread and reasons behind dispersal. Potential commonalities in the sites where $D$. geminata was found and confirmed in Grand Teton National Park include lake outlet streams and high traffic areas; four of the seven streams where D. geminata was found are lake outlet streams and all streams were noted as high traffic areas (no less than 10 people present at the stream).

\begin{tabular}{|l|l|}
\hline Sample Locations & $\begin{array}{l}\text { D.geminata Abundance } \\
\text { (cells } / \mathbf{m}^{2} \text { ) }\end{array}$ \\
\hline Phelps Lake Outlet & $1.5^{*} 10^{8}$ \\
\hline Taggert Lake Outlet & $2.4^{*} 10^{7}$ \\
\hline Phelps Lake Inlet & $2.1^{*} 10^{6}$ \\
\hline Jenny Lake Outlet & $8.4^{*} 10^{5}$ \\
\hline Flat Creek & $2.9^{*} 10^{7}$ \\
\hline Leigh Lake Outfall & $1.3^{*} 10^{4}$ \\
\hline Fish Creek & $9.2^{*} 10^{5}$ \\
\hline Blacktail Spring Creek & 0 \\
\hline Kelly Warm Springs & 0 \\
\hline Triangle X Creek & 0 \\
\hline Two Oceans Creek & 0 \\
\hline Bradley Lake Outlet & 0 \\
\hline String Lake Outlet & 0 \\
\hline Lizard Creek & 0 \\
\hline Arizona Creek & 0 \\
\hline Polecat Creek & 0 \\
\hline Granite Creek & 0 \\
\hline Berry Creek & 0 \\
\hline Moran Creek & 0 \\
\hline Pilgrim Creek & 0 \\
\hline Pacific Creek & 0 \\
\hline Ditch Creek & 0 \\
\hline Spread Creek & 0 \\
\hline $\begin{array}{l}\text { Snake River @ South } \\
\text { Park Bridge }\end{array}$ & 0 \\
\hline
\end{tabular}

Table 1: Illustrates the abundance of $D$. geminata in sample locations. Note the evident trend of $D$. geminata abundance in lake outlet streams. 


\section{$\downarrow$ Literature CiTED}

Kilroy, C. 2006. Ecological studies on Didymosphenia geminata. National Institute of Water and Atmospheric Research Ltd.

Patrick, R. and C.W. Reimer. 1966. The diatoms of the United States. Vol. 1. The Academy of Natural Sciences of Philadelphia. 688.

Prescott, L.M., J.P. Harley and D.A. Klein. 2005. Microbiology Sixth Edition. The McGraw Hill Companies, Inc. 560, G-8.
Schmidt, L.M. 2007. A sensitive genetic-based detection capability for Didymosphenia geminata: phases two and three. CBER Contract Report 62. MAF Biosecurity New Zealand.

Spaulding, S. and L. Elwell. 2007. Increase in nuisance blooms and freshwater expansion of the freshwater diatom Didymosphenia geminata: recommendations for response. USEPA White Paper. 


\section{Appendix A}

\begin{tabular}{|c|c|c|c|c|}
\hline Streams Researched & $\begin{array}{l}\text { GPS Coordinates } \\
\text { Top of Reach }\end{array}$ & $\begin{array}{c}\text { Concentrations } \\
\left.\text { (D. geminata cells } / \mathbf{m}^{2}\right)\end{array}$ & $\begin{array}{l}\text { Lake Outlet } \\
\text { (Y/N) }\end{array}$ & $\begin{array}{l}\text { People Present? } \\
\text { (Y/N) }\end{array}$ \\
\hline Phelps Lake Outlet & $\mathrm{N} 43^{\circ} 37.565^{\prime} \mathrm{W} 110^{\circ} 47.025^{\prime}$ & $1.5^{*} 10^{8}$ & $\mathrm{Y}$ & $\mathrm{Y}$ \\
\hline Taggert Lake Outlet & $\mathrm{N} 43^{\circ} 41.806^{\prime} \mathrm{W} 110^{\circ} 44.162^{\prime}$ & $2.4^{*} 10^{7}$ & $\mathrm{Y}$ & $\mathrm{Y}$ \\
\hline Phelps Lake Inlet & $\mathrm{N} 43^{\circ} 39.139^{\prime} \mathrm{W} 110^{\circ} 48.365^{\prime}$ & $2.1 * 10^{6}$ & $\mathrm{~N}$ & Y \\
\hline Jenny Lake Outlet & $\mathrm{N} 43^{\circ} 44.748^{\prime} \mathrm{W} 110^{\circ} 43.624^{\prime}$ & $8.4^{*} 10^{5}$ & $\mathrm{Y}$ & $\mathrm{Y}$ \\
\hline Flat Creek & $\mathrm{N} 43^{\circ} 29.671^{\prime} \mathrm{W} 110^{\circ} 45.401^{\prime}$ & $2.9 * 10^{7}$ & $\mathrm{~N}$ & $\mathrm{~N}$ \\
\hline Leigh Lake Outfall & $\mathrm{N} 43^{\circ} 47.846^{\prime} \mathrm{W} 110^{\circ} 43.715^{\prime}$ & $1.3 * 10^{4}$ & $\mathrm{Y}$ & $\mathrm{Y}$ \\
\hline Fish Creek & $\mathrm{N} 43^{\circ} 29.880^{\prime} \mathrm{W} 110^{\circ} 52.344^{\prime}$ & $9.2 * 10^{5}$ & $\mathrm{~N}$ & $\mathrm{Y}$ \\
\hline Blacktail Spring Creek & $\mathrm{N} 43^{\circ} 40.521^{\prime} \mathrm{W} 110^{\circ} 41.726^{\prime}$ & 0 & $\mathrm{~N}$ & $\mathrm{Y}$ \\
\hline Kelly Warm Springs & $\mathrm{N} 43^{\circ} 38.410^{\prime} \mathrm{W} 110^{\circ} 37.099^{\prime}$ & 0 & $\mathrm{~N}$ & $\mathrm{Y}$ \\
\hline Triangle X Creek & $\mathrm{N} 43^{\circ} 45.570^{\prime} \mathrm{W} 110^{\circ} 34.990^{\prime}$ & 0 & $\mathrm{~N}$ & $\mathrm{~N}$ \\
\hline Two Oceans Creek & $\mathrm{N} 43^{\circ} 52.522^{\prime} \mathrm{W} 110^{\circ} 29.309^{\prime}$ & 0 & $\mathrm{~N}$ & $\mathrm{~N}$ \\
\hline Bradley Lake Outlet & $\mathrm{N} 43^{\circ} 42.742^{\prime} \mathrm{W} 110^{\circ} 43.938^{\prime}$ & 0 & $\mathrm{Y}$ & $\mathrm{Y}$ \\
\hline String Lake Outlet & $\mathrm{N} 43^{\circ} 47.041^{\prime} \mathrm{W} 110^{\circ} 43.678^{\prime}$ & 0 & $\mathrm{Y}$ & $\mathrm{Y}$ \\
\hline Lizard Creek & $\mathrm{N} 44^{\circ} 00.411^{\prime} \mathrm{W} 110^{\circ} 40.848^{\prime}$ & 0 & $\mathrm{~N}$ & $\mathrm{~N}$ \\
\hline Arizona Creek & $\mathrm{N} 43^{\circ} 58.474^{\prime} \mathrm{W} 110^{\circ} 38.623^{\prime}$ & 0 & $\mathrm{~N}$ & $\mathrm{~N}$ \\
\hline Polecat Creek & $\mathrm{N} 44^{\circ} 06.624^{\prime} \mathrm{W} 110^{\circ} 41.575^{\prime}$ & 0 & $\mathrm{~N}$ & $\mathrm{Y}$ \\
\hline Granite Creek & $\mathrm{N} 43^{\circ} 36.386^{\prime} \mathrm{W} 110^{\circ} 48.317^{\prime}$ & 0 & $\mathrm{~N}$ & Y \\
\hline Berry Creek & $\mathrm{N} 43^{\circ} 59.837^{\prime} \mathrm{W} 110^{\circ} 42.678^{\prime}$ & 0 & $\mathrm{~N}$ & $\mathrm{~N}$ \\
\hline Moran Creek & $\mathrm{N} 43^{\circ} 51.707^{\prime} \mathrm{W} 110^{\circ} 45.256^{\prime}$ & 0 & $\mathrm{~N}$ & $\mathrm{~N}$ \\
\hline Pilgrim Creek & $\mathrm{N} 43^{\circ} 54.468^{\prime} \mathrm{W} 110^{\circ} 34.885^{\prime}$ & 0 & $\mathrm{~N}$ & $\mathrm{~N}$ \\
\hline Pacific Creek & $\mathrm{N} 43^{\circ} 51.209^{\prime} \mathrm{W} 110^{\circ} 30.747^{\prime}$ & 0 & $\mathrm{~N}$ & $\mathrm{~N}$ \\
\hline Ditch Creek & $\mathrm{N} 43^{\circ} 39.809^{\prime} \mathrm{W} 110^{\circ} 37.728^{\prime}$ & 0 & $\mathrm{~N}$ & $\mathrm{~N}$ \\
\hline Spread Creek & $\mathrm{N} 43^{\circ} 47.404^{\prime} \mathrm{W} 110^{\circ} 32.233^{\prime}$ & 0 & $\mathrm{~N}$ & $\mathrm{~N}$ \\
\hline $\begin{array}{l}\text { Snake River@South Park } \\
\text { Bridge }\end{array}$ & $\mathrm{N} 43^{\circ} 23.095^{\prime} \mathrm{W} 110^{\circ} 44.779^{\prime}$ & 0 & $\mathrm{Y}$ & Y \\
\hline
\end{tabular}

